\title{
Words of congratulation from one side of the Pacific Rim to the other
}

\author{
Rachel S. Franklin ${ }^{1}$
}

Published online: 9 March 2017

(C) The Japan Section of the Regional Science Association International 2017

Regional Science is a discipline, but it is also a family of sorts-a family of researchers, conferences, associations, and-of course-journals. As in any family, it is important to come together to celebrate the milestones. Where regional science journals are concerned, older publications such as Papers in Regional Science, the Journal of Regional Science, and the Annals of Regional Science were pathbreaking, laying the foundation for newer members of the journal family, such as Region or Regional Science Policy and Practice. However, although all of these journals are global in scope in terms of authorship and topical areas of study, their homes are in the United States and Europe. What has been missing is an Asian member of the regional science journal family. This now changes with the inaugural issue of the Asia-Pacific Journal of Regional Science. As members of the regional science family, we come together here, in the pages of this new journal, to commemorate the event! The best of wishes for the future of this new member of the regional science journal family!

A new regional science journal is momentous for the entire field. It is also yet one more indication of the historical and prominent role of the Japan Section of the Regional Science Association International and Asian regional scientists more broadly within the larger field. We know already of the Japan Section's willingness to support new members of the family. Together with the Western Regional Science Association, the Japan Section worked to create the Pacific Regional Science Conference Organization, or PRSCO. Over the decades, this group has been very successful in bringing together regional scientists throughout Asia and the Pacific Rim-and, indeed, the entire world. Thus, as one of the linchpins of regional science worldwide, the Japan Section's willingness to take on this new

Rachel S. Franklin

rachel_franklin@brown.edu

1 Spatial Structures in the Social Sciences (S4) / Population Studies and Training Center (PSTC), Brown University, Providence, RI, USA 
responsibility as producer and keeper of knowledge is another symbol of its central role in the larger regional science family.

A hallmark of regional science, beyond the words of knowledge exchanged inside meeting rooms and in the pages of journals, has been the collegiality of its members. Over the decades, friendships have blossomed and networks have formed and strengthened. It is in this spirit of friendship and collaboration that I offer these final words of congratulation. Our family is stronger because of efforts such as the new Asia-Pacific Journal of Regional Science and for this we should all be grateful. After all, it is family that makes a home and we are fortuitous indeed to be able to call regional science our home. 